\title{
Co-governance and upgrading in the South African small-scale fisheries value chain
}

\author{
Carsten R. Wentink ${ }^{1^{*}}$ (D) Serge Raemaekers ${ }^{2}$ and Simon R. Bush ${ }^{1}$
}

\author{
* Correspondence: \\ carstenwentink@hotmail.com \\ ${ }^{1}$ Environmental Policy Group, \\ Wageningen University, \\ Wageningen, Netherlands \\ Full list of author information is \\ available at the end of the article
}

\begin{abstract}
This paper identifies new forms of public-private modes of governance for achieving collective forms of value chain upgrading in South African small-scale fisheries. Our analysis focuses on the different stages of implementing the 2012 small-scale fisheries policy designed to promote collective action and enable inter alia smallscale rock lobster fishers to improve rights allocation and the terms of their inclusion in export value chains. The results indicate that collective action by fishers is imperative to achieve upgrading by small-scale fishers in value chains, and that constructive and well defined relations with private as well as extra-transactional actors, like government and NGOs, are essential to the success of collective action as an upgrading strategy. By combining insights from interactive governance and global value chain governance we propose a new analytical framework that goes beyond upgrading alone to better understand the influences of collective action and the role of these extra-transactional actors in the development of small-scale fisheries.
\end{abstract}

\section{Introduction}

Small-scale fisheries (SSF) generate livelihoods, employment and income through harvesting, processing and marketing for an estimated 250 million people (Berkes et al. 2001; Béné 2006; Jentoft and Chuenpagdee 2015). However, these fishers are often marginalised in global value chains because they are unable to negotiate favourable terms of incorporation in these chains, including access to credit and access to cold chain infrastructure (e.g. Bush and Oosterveer 2007; Ponte 2008). They are also often less capable of complying with export market food safety, traceability and eco-certification requirements (Béné et al. 2005; Pérez-Ramírez et al. 2012; Bailey et al. 2016b; Bjorndal 2014). Their inability to re-negotiate their terms of incorporation is strongly related to their social relations with buyers in these chains. For instance, patronage relations between fishers and their immediate buyers can enable fishers to gain market access and meet produce requirements, but often at the cost of equitable distribution of market benefits (e.g. Bush 2004; Kusumawati et al. 2013). Overcoming these patronage relations are therefore commonly seen as a means of empowering fishers to upgrade their position in value chains, either by developing strategies for increasing the value of their products and/or reducing the risk of detrimental trading relations (Bjorndal 2014; Adhuri et al. 2016).

(c) The Author(s). 2017 Open Access This article is distributed under the terms of the Creative Commons Attribution 4.0 International License (http://creativecommons.org/licenses/by/4.0/), which permits unrestricted use, distribution, and reproduction in any medium, provided you give appropriate credit to the original author(s) and the source, provide a link to the Creative Commons license, and indicate if changes were made. 
Supporting fishers to 'upgrade' their position in value chains is commonly thought to require external intervention by 'extra-transactional' actors independent of the social relations that structure these value chains and/or collective approaches by fishers that can enable fishers to overcome prevailing social relations (see Mitchell and Coles 2011; Bailey et al. 2016a; Bailey et al. 2016b). However, little attention has been given to either what forms of external intervention or collective forms of action, can enable small-scale fishers to (re)negotiate market relationships (cf. Jentoft and Davis 1993; Hellin et al. 2009; Markelova et al. 2009). In other sectors it has been observed that collective action and upgrading by small-holders rarely 'self-organises' (Hellin et al. 2009), and that the configuration of power relations in the chain needs to be reoriented to realise upgrading strategies. As variously noted (e,g. Markelova et al. 2009; Hellin et al. 2009), interventions are therefore often required to assist small holders to organise collective forms of organisation and upgrading, often by extra-transactional actors, such as states and civil society groups.

In this paper we explore attempts by the South African government to support West Coast rock lobster (Jasus lalandii) fishers in the Western Cape province to improve their access to fishery resources and export oriented value chains to secure their livelihoods. This state intervention has come in two distinct phases. The first phase saw the allocation of individual 'Interim Relief' (IR) fishing permits since 2007 in response to an order of Court recognising traditional fishing rights and the need to provide access measures while a new Policy was being developed ( Isaacs 2011; Sowman et al. 2014). Through the introduction of the Interim Relief system 1500 permit holders have obtained access to high-value West Coast rock lobster, coupled with limited access to migratory and lower value line-fish species in the Western Cape and Northern Cape provinces (Isaacs 2011; Sowman et al. 2014). However the Interim Relief system fishers have suffered from small quotas, a lack of suitable vessels and capital to maintain these vessels, and unfavourable market relations in value chains.

The second phase is the implementation of a new SSF policy, which was gazetted in 2012 but is yet to be implemented. The SSF policy seeks to upgrade the position of small-scale fishers in value chains by improving their collective bargaining power through the formation of Community Based Legal Entities (CBLE), which could be structured as cooperatives, trusts, associations and other suitable formats. The policy aims to support CBLEs in value chains through extensive financial assistance and capacity building instruments related to various post-harvest activities (e.g. processing, storing, packaging, marketing, transporting and exporting of fish); and basic business skills such as finance management, human resource management, logistics, and business management. Moreover these CBLEs are intended to play a key role in fisheries management through the allocation of collective fishery rights (DAFF 2012). While this new policy clearly advocates upgrading through collective action, much uncertainty remains on how it will realise the goals in terms of both resource stewardship and market-based poverty alleviation, and how instrumental the CBLEs can be in this regard.

Against this background we analyse whether and how private chain and extratransactional (state) actors can support the establishment of collective approaches, such as CBLEs, as an upgrading strategy for small scale fishers in the rock lobster value chain. More specifically we focus on (1) the existing market relations between 
individual fishers and upstream actors and associated upgrading potential, (2) the effect of collective action on the reconfiguration of these market relations and upgrading potential, and (3) the governance approach of public actors towards community-led upgrading and value chains. We explore these questions through a hybrid analytical framework. First, we use Global Value Chain (GVC) analysis (Humphrey and Schmitz 2000; Gereffi et al. 2005; Gereffi and Lee 2012) to focus on how trade relations influence the ability of value chain actors to upgrade their production (Humphrey and Schmitz 2000). Second, we use an adaptation of interactive governance theory (Kooiman 2003; Kooiman et al. 2005; Jentoft and Chuenpagdee 2015) to examine the type and function of extra-transactional (also described as 'horizontal') forms of support to value chain actors such as small scale fishers (cf. Gibbon et al. 2009). This framework allows us to redress the apparent gap in knowledge about the role of extratransactional actors such as states in their attempt to organising collective forms of upgrading in small scale fisheries in global value chains.

The following section provides a short overview of the literature on collective forms of upgrading in GVCs, and the under-theorized influence of extra-transactional actors in this regard. We then present two cases related to upgrading small-scale fishers in the lobster value chain; the first outlining upgrading attempts through individual action, and the second outlining an exceptional case where fishers engage in value chains through a newly formed CBLE. Finally, we discuss these results by placing upgrading in a broader institutional context, in which both private and extratransactional actors have a determining role to play.

\section{Governing upgrading in global value chains}

Upgrading most commonly refers to the ways in which producers and other firm actors upgrade their position and/or process of production in value chains, either by 'doing something better', renegotiating the social relations in which they are embedded, or reducing the risk and vulnerability of their production practices (Ponte and Ewert 2009; Mitchell and Coles 2011; Tolentino-Zondervan et al. 2016). There are three generalised forms of upgrading that can be applied to resource sectors like fisheries (see Gibbon and Ponte 2005; Humphrey and Schmitz 2000; Mitchell and Coles 2011). First, process upgrading, involves the transformation of inputs into outputs more efficiently by re-organizing the production system or introducing superior technology. Second, product upgrading, involving a move into more sophisticated product lines. And third, functional upgrading, involving the acquisition of new roles and skills that go beyond the primary role or activity in the chain - for example, marketing and processing in addition to production alone.

The combination of these upgrading strategies is also seen as a means of achieving social and environmental goals by incentivising private actors in markets to foster improvements in their own or their suppliers' production practices (Bush et al. 2015; Gereffi and Lee 2016; Poulsen et al. 2016). But aligning private product, process and functional upgrading practices of producers, like fishers, to meet what are ostensibly public social and environmental goals, requires intervention from market coordinating and/or 'extra transactional' regulatory actors like the state and NGOs (Riisgaard et al. 2010; Neilson 2014; Gereffi and Lee 2016). By focusing on the conditions and rules that these actors set for producers we can not only identify how incentives for producers 
are aligned with public goals, but also identify modes of coordination and interaction in and through value chains that can support and facilitate this alignment. As noted by various authors (Macfadyen and Corcoran 2002; Webber et al. 2010; Coles and Mitchell 2011), producers that are less able to upgrade due to limited financial and human capacity, such as small scale fishers, are more in need of such support and facilitation through the formation of collective organisations like cooperatives.

The level of support and facilitation producers receive is therefore largely dependent on the relations these producers have with market and extra transactional actors in vertical and horizontal dimensions in and around value chains. Vertical relations in value chains are those structured around transactions between buyers and suppliers. But moving beyond the economic dimensions GVC analysis provides a framework to analyse the economic relations between the actors that structure these transactions and describe the form and function of chains as a whole (see Gibbon et al. 2009; Bair and Palpaucer 2015). Gereffi et al. (2005) for instance, describes three types with different degrees of coordination and power inequity between buyers and suppliers. They first characterise 'arm's length market' relations, with low levels of complexity and high levels of supplier capabilities to access and operate in the chain. Second, collaborative network relations, that include lower levels of complexity and lower supplier capabilities. And third, highly coordinated 'quasi hierarchy' relations, with high levels of complexity and low supplier capabilities. In the context of small-holder equity, the higher the complexity and the lower the capabilities of suppliers, the less equitable decision making and the stronger lead-firm coordination becomes. As variously argued (Gereffi et al. 2005; Gibbon et al. 2009; Gereffi and Lee 2012), by observing these various dimensions of lead-firm coordination insights are gained into the degree of control and power in any given chain, including how equitable benefits are distributed, and ultimately what opportunities and constraints for small-scale producers to upgrade their position in the chain can be identified.

The horizontal dimension refers to the role of extra-transactional actors in supporting producers (and indeed other chain actors) to upgrade. Although state and NGO involvement is widely observed in value chains in terms of both setting trade and resource regulation and standards, or training and support in support of upgrading, it remains under-theorized (Gereffi and Lee 2016). Recent attention has been given to the consequences for mobilising and moderating state involvement in fisheries related value chain governance (Hamilton-Hart and Stringer 2016), while others have focused on the fundamental role of state regulation in promoting the greening of maritime industries such as shipping (Poulsen et al. 2016). But these and other studies have focused mainly on state intervention in upgrading in terms of regulation. Instead, following Gereffi and Lee (2016) we need to go beyond regulation alone to understand value chain governance as the synthesis of private (corporate), social (NGO) and public (state) modes of governance in theorizing about new patterns of governance in GVCs. However, little consideration has been given to providing a more precise classification of how extra-transactional interventions can be classified and understood in the context of collective forms of upgrading, that go beyond industrial clustering, to reach social and environmental outcomes.

We therefore offer a classification of horizontal coordination of collective upgrading by extra-transactional actors that is based on interactive governance theory, which focuses on a wide range of public and private interactions, and the identification of 
modes of governance that can be applied to guiding those interactions, with the goal of solving complex societal problems (Kooiman and Bavinck 2005; Jentoft and Chuanpagdee 2015). Interactive governance theory is based on the assumption that the act of governing is both constituted by and instrumental in facilitating social interaction (Kooiman 2003). It gives attention to how different modes of governance emerge at different spatial and temporal scales and provide rules, norms and mechanisms that determine why, how and when interactions take place. It presents a useful approach to identifying different modes of governmental intervention in governing collective upgrading in value chains.

Three general modes of interactive governance have been identified by Kooiman (2003). Self-governance refers to situations in which actors are taking care of themselves outside the purview of the government, implying that state-intervention in value chains and collective forms of upgrading is limited to non-existent. Co-governance refers to instances where societal parties join hands with a common purpose in mind, staking their identity and autonomy in the process. A key assumption here is that no single actor is in control. Co-governance manifests itself in numerous ways including communicative governance, public-private-partnerships, networks, regimes and comanagement (Kooiman 2003). Hierarchical governance is referred to as the most classical type of governance being characteristic for interactions between state and society. This is a top-down style of governance expressed through policies and law with the state as the central governing unit in society (Kooiman 2003). While these are ideal types, Kooiman et al. (2005) notes that no one of these modes of governance exist in isolation from the other. Nevertheless, we argue that as ideal types they offer a heuristic for classifying specific relations such as government intervention in value chains. They also offer an opportunity for opening a more precise explanation of the kind of synergistic value chain governance identified by Gerreffi and Lee.

\section{Methodology}

Data was collected through five field visits between October 2013 and January 2014 in the SSF communities of Doringbaai and Kleinmond (Fig. 1). These sites were selected based on discussions with stakeholders about which SSF communities could best illustrate the extent to which the state policy affects upgrading through collective action. Doringbaai provided the only example in the Western Cape of collective action through a CBLE related cooperative. Kleinmond provided a comparison to Doringbaai as a site in which small-scale fishers are engaged in value chain transactions on an individual basis, making their situation comparable to most other small-scale rock lobster fishers in the Western Cape. In both communities, the focus was on those fishers that had received IR permits. Combined these sites provide insights into the potential of the SSF policy to catalyse collective action and value chain upgrading.

Semi-structured interviews with 20 fishers and focus groups with 21 fishers were held to map value chain structures, identify opportunities and constraints to collective action and upgrading and the role of extra-transactional actors in this regard. Results were cross-checked and complemented by interviews with one retailer, six processing and marketing companies for lobster, five interviews with SSF NGO representatives and two experts. Key insights on the SSF policy and the envisaged CBLEs were also gleaned through the attendance of public hearings on the SSF policy and the amendment of the related Marine Living Resources Act at the South African parliament, 


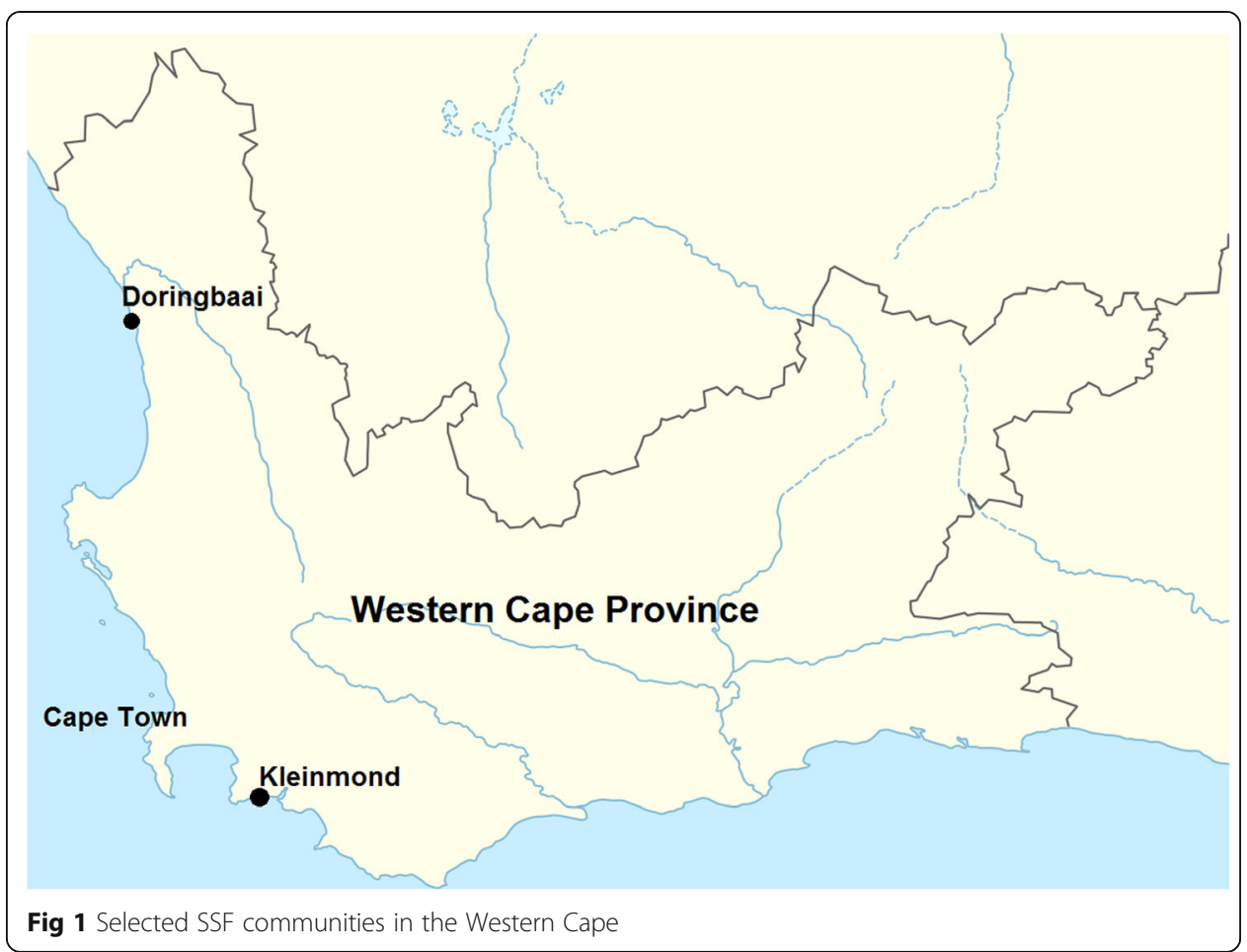

where the policy was discussed by experts, stakeholders, government officials and members of parliament. Preliminary results were further discussed at a roundtable session with nine experts and stakeholders.

\section{Individual fishers in the lobster value chain}

IR permits are allocated to small-scale fishers, allowing them to catch a relatively small individual quota, amounting to $138 \mathrm{~kg}$ 's of lobster in the 2013/2014 season. With few alternative sources of income these fishers are highly dependent on income from this chain. IR permit holders commonly sell live lobster per kilogram with prices varying approximately between R120 (\$11.30) and R160 (\$15.07) per kg (see Fig. 2). These prices are offered by local vertically integrated processing and marketing companies and foreign buyers. Many of these processing and marketing companies have established powerful positions in value chains as they have historically been the benefactors of large scale allocations of fishing rights for lobster, as well as other marine resources (see e.g. Ponte and Van Sittert 2007), allowing them to develop extensive fishing, processing and exporting operations. These companies play a key role in upgrading the position of small-scale fishers in the lobster value chain.

All buyers aim to sell all of their lobster in Asian markets, which offer high but volatile prices ranging from $\$ 20$ to $\$ 76$ per $\mathrm{kg}$. Because lobster is live-traded it is also a high risk product, requiring a high level of requirements being placed on the catch and transport. In view of the significant financial value of live lobster, coupled with concerns by the processing and marketing companies over the high mortality rates of lobster caught by IR fishers, these buyers exercise a high degree of coordination over their suppliers in coastal communities. As one interviewee described, this coordination is akin to "keeping a hawks eye on what our suppliers are doing". Buyers try to 


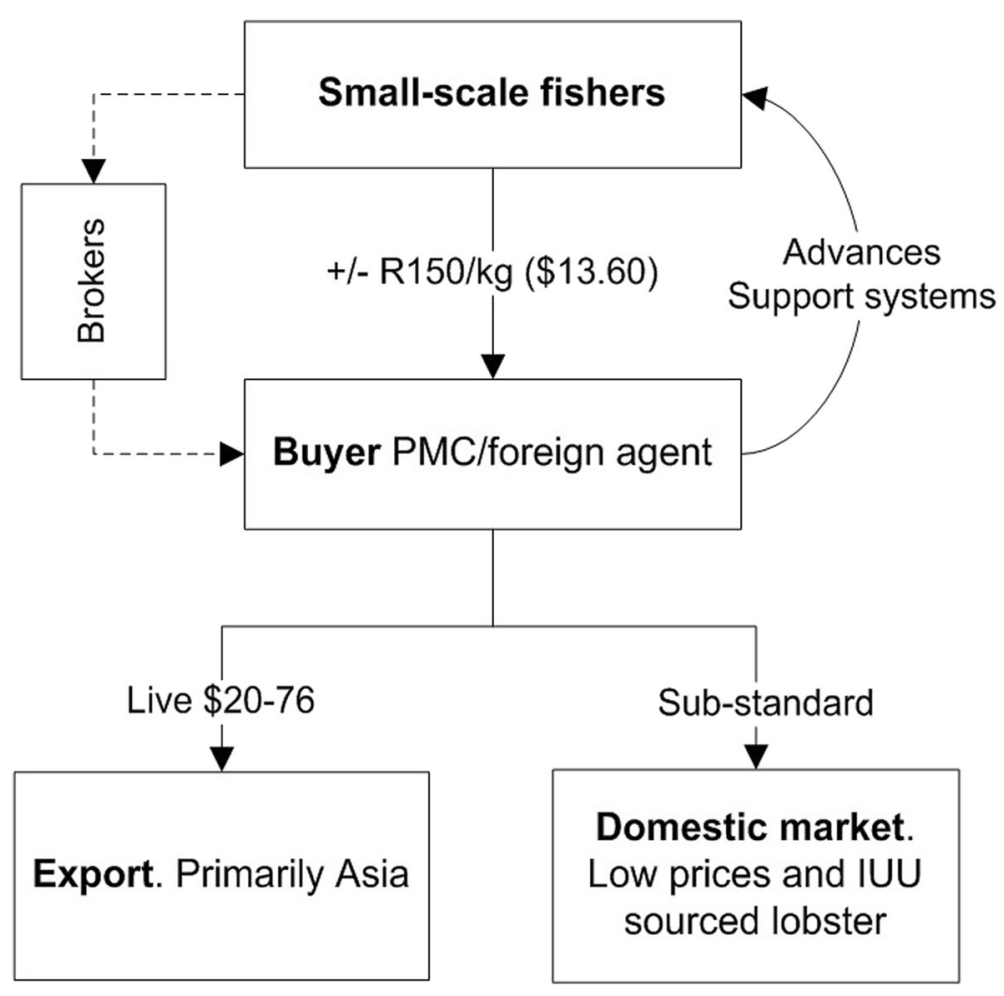

Fig 2 The lobster value chain

influence the catching process by providing training, giving feedback on the quality and by providing special equipment such as protective bags in which lobster can be kept to reduce mortality.

Given the volatility and risk of supply buyers aim to bind fishers to their business by positioning themselves in the value chain as service providers. These 'services' include support with fishery related activities such as boat registration, licensing and accounting, the purchasing of vehicles for local 'agents or brokers', and non-fishery related services such as health insurance and property conveyance. Buyers also bind suppliers by providing unregulated credit (i.e. cash loans and advances). Fishers often do not repay this credit within stipulated timeframes, forcing them to sell next season's lobster to the same buyer at low prices (similar to what is observed in other fisheries, see Bush 2004; Johnson 2010; Ruddle 2011). Independent foreign buyers are particularly known for this practice while local buyers often claim to put some restrictions on credit to fishers linked to the value of the yearly individual quota. Additionally, IR fishers commonly sell lobster through brokers due to their low quotas and the preference of these fishers to be paid in cash. Brokers create an economy of scale around these IR fishers by grouping them to ensure a larger accumulated supply to the buyer. Meanwhile many brokers are being accused of incomplete payments to fishers and creating contracts with unfavourable buyers in exchange for a high commission paid by these buyers.

Overall it is evident that the unequal power relations between individual fishers and actors further upstream in the chain results in an exploitative relation that is taking place outside the purview of governmental authorities. Against this backdrop of unfavourable value chain transactions and the unregulated credit systems in particular, 
fishers perceive their bargaining position in the lobster value chain to be weak. Therefore there is a common desire among fishers to improve the prices paid for their lobster and to engage in value chain upgrading, particularly through post-harvest activity. The ability of these fishers to do so, however, strongly depends on their relation with other fishers in their community, as well as brokers and buyers.

Due to the quasi-hierarchical nature of these value chain relations upgrading by small-scale fishers is particularly challenging. As seen elsewhere, individual small-scale fishers are constrained by limited market knowledge, processing infrastructure and skills, funding and institutional structure to engage in complex upgrading strategies (e.g. Coles and Mitchell 2011). Support by the downstream firms with whom the fishers are currently involved is therefore necessary to retain access to export markets and to engage in upgrading activities. However, although these buyers often claim to support pro-poor value chains they also face a conflict of interest over the distribution of benefits in the value chain; reflected in the currently unfavourable quasi-hierarchical chain coordination. While buyers claim to support these fishers' aspirations to engage in function upgrading, such as taking on a marketing role in the chain, doing so would likely infringe on the value-added activities of these buyers (cf. Humphrey and Schmitz 2000). It therefore appears more likely that these buyers would rather support process and product upgrading, such as reducing post-harvest lobster mortality rates and to ensure reliable procurement, which are in the interest of the fishers as well as buyers. However, given the quasi-hierarchical nature of these relations such support does not necessarily result in more equitable transactions.

Interviews with fishers also revealed that upgrading support within the chain is unlikely because buyers do not trust those fishers operating under IR permits. Fishers and buyers alike pointed out that IR permit holders often delegate commercial fishers to land their quota, who then sell the higher quality lobster while leaving poorer quality lobster susceptible to higher mortality rates for the IR permit holders. In other cases community members who are not bona fide fishers have illegitimately obtained IR permits. Support from buyers is also constrained by the fact that they are also involved in the commercial lobster fishery, thereby being in direct competition with the small-scale sector for quotas. In addition these buyers often accuse small-scale fishers of fraud, claiming that they sell catch beyond their quota with invalid documents that cannot be used for export. Conversely, fishers accuse buyers of fraud as they pool lobster from different sources in holding tanks, allocating higher mortalities and lower prices to the IR lobster without any form of traceability. The overall result is that some buyers have stopped buying from IR fishers. Meanwhile the relation with upstream firms who do procure from these fishers is negatively characterized by distrust, allegations of misconduct by fishers, as well as upstream actors and a lack of upgrading potential.

\section{Towards collective action and strategic partnerships in the lobster value chain}

The constraints to individual IR fishers to invest in upgrading shows that alternative strategies are required, including collective action (as seen in other sectors Shiferaw et al. 2009; Blandon et al. 2009; Markelova et al. 2009). Interviews revealed that downstream buyers point to the potential for further upgrading support to fishers who operate as a collective through the proposed CBLEs linked to the new SSF policy. They argue that the larger volumes and greater reliability of these CBLEs 
could secure long-term business relations with fishers. Buyers interviewed note various potential improvements that would ensue from the collective organisation of fishers, including: 1. shared ownership of existing processing facilities, such as live-holding tanks and transport; 2. shared investment in improved harvesting equipment suitable for the combined catch from numerous IR fishers; and 3. improved access to the export markets through processing and marketing services, enabling fishers to catch and sell lobster in periods when the international market price is particularly profitable.

While collective action by fishers is considered a condition for this support, buyers are also more likely to engage with stable CBLEs due to changes in fishing rights allocations that are planned as part of the SSF Policy. Some buyers expressed concern that in order to create equity in the fisheries sector, larger harvest allocations may be afforded to the SSF sector, likely at the expense of allocations currently granted to established companies which also procure lobster from the SSF sector. Such a situation may create greater mutual dependency, where CBLEs depend on buyers for upgrading support and market access and buyers become dependent on CBLEs to ensure the viability of their processing and export operations. Meanwhile the incentive to indebt vulnerable individual fishers through advance payments may also be increased, giving even more importance to the setup of CBLEs which can reduce the vulnerability of fishers to exploitative and binding transactions.

In view of the potential of collective action for upgrading and equity in transactions the Ukondleka fisheries cooperative was established in Doringbaai. Ukondleka (meaning 'we are rising' in local isiXhosa and isi Zulu languages) has often been referred to as a pilot for the SSF policy implementation by civil society groups and the fisheries authority, and was established with support from civil society groups and the Department of Trade and Industry. The Masifundise Development Trust and the associated Coastal Links fisher network played an important role during the start-up phase of the cooperative, by building grass-root level support and awareness through information sessions and workshops. The Department of Trade and Industry (DTI) subsequently provided financial and material support, including new fishing vessels. Ukondleka was the only functioning producer marketing group for small-scale lobster fishers in the Western Cape. A number of functional, process and product upgrading activities potentials were realised by the Ukondleka fisheries cooperative, where over a hundred fishers with IR permits engaged in the lobster value chain collectively.

By setting up a cooperative structure, fishers collectively gained new capabilities for self-governance. Ukondleka involved 12 smaller cooperatives setup by DTI within the community. Elected chairs of these primary cooperatives formed the Ukondleka board which guided various fishery and marketing activities, laid out in a cooperative constitution. Many of these tasks were formerly organized by brokers and buyers. The increased ability to 'self-govern' these activities through a cooperative system led to the expulsion of controversial chain actors including brokers and foreign buyers. Instead the cooperative built a more durable partnership with a vertically integrated processing and marketing company. As a result, individual fishers no longer took credit from buyers that tied them to potentially exploitative transactions. Instead a floor price of R160/kg (US\$15.07) was agreed on since 2013, with a possibility of higher prices in particularly profitable periods when the price can rise above R180/kg (US\$16.95). This 
is an improvement on the prices offered to individual fishers that can be as low as R120/kg (US\$11.30). Meanwhile individual fishers were no longer able to engage in transactions with different buyers throughout the season. Instead transactions were guided by the cooperative and fishers became more accountable for the quality and legality of delivered produce. As a result the buyer noted a reduction in lobster mortality rates and a lower likelihood of dealing with illegally procured lobster. Overall the cooperative enhanced the capability of fishers to meet complex produce requirements and renegotiate their position in the value chain.

The improvement of market relations through the cooperative was also characterized by extensive support by the buyer that went beyond the services provided to individual fishers. For example, the buyer provided training on cooperative governance (e.g. management skills, budgeting skills and administration skills) and directly supported plans for a range of upgrading activities including the provision of equipment that can increase harvesting efficiency (i.e. improved boats and engines), as well as post-harvest infrastructure such as live holding tanks in the coastal community where the cooperative is situated, and transport by fishers from these tanks to processing and export facilities. Through the Ukondleka cooperative fishers were able to increase their capabilities and reduced the power asymmetry evident under individual market coordination. Although the new buyer-cooperative coordination can be seen as quasi-hierarchical, it became more equitable and showed evidence of shared learning and feedback that is characteristic of relational forms of chain coordination. In short, both parties in the transaction were making a mutual effort to improve the products, processes and functions of production.

Despite these benefits the Ukondleka cooperative has struggled to grow due to frictions among the smaller cooperatives, disputes over the preferred buyer and a general lack of support through training and financial accounting tools and services. Internal conflict within the cooperative led to elite capture by various leading individuals of optimal market relations with buyers, and in doing so undermined equity goals. Efforts to establish comparable structures in the future will have to take this risk into account as well as a need for on-going capacity building and business-running mentoring. Despite this, the lessons learnt from the Ukondleka cooperative are still relevant for the wider implementation of CBLEs under the new SSF policy today. For instance, the case shows that collective action can improve upgrading potential and that extratransactional actors can play an important role in building and maintaining structures for self-governance by fishers to achieve this. The question for those observing this model in South Africa was whether these lessons learnt could be replicated under the SSF policy.

\section{Collective action and state-intervention}

The SSF policy aims to allocate community fishing rights and establish CBLEs through a bottom-up process, in which individual fishing communities determine local management structures that best serve their specific interests and needs. A CBLE could for instance be a trust, a cooperative or a 'section 21 company' designed to deliver (social) services. Regardless of the chosen configuration, CBLEs are intended to develop capabilities for self-governance in SSF communities, while the SSF policy implementation programme aims to support their establishment and administration. Apart from 
material and financial services, customised training programmes are proposed to ensure that the CBLEs can play a role in fisheries co-management, value chain upgrading and the overall improvement of livelihoods in respective SSF communities.

As outlined by DAFF (2012), the SSF policy proposes an allocation of communal fishing rights to CBLEs, which in turn means that that these entities can partake in the decision on who are active bona fide fishers in the community, exercise communal fishing rights, determine how fish is sold, and how members will be involved in value adding activities. In addition the SSF policy proposes eligibility of CBLEs to various instruments to increase benefits to fishing communities from the allocation of communal fishing rights, including subsidy schemes and skills training for the storage, processing, packaging, marketing, transport and export of fish; support of SSF owned marketing companies; development of a small-scale fisheries label; and the establishment of a comprehensive development finance scheme for fisheries.

Due to the lengthy process of accommodating legal and institutional needs by the government required to implement the SSF policy no CBLE has been formalized to date. Instead only a limited amount support has been provided by DTI without continued coordination with the fisheries authority. Apart from its involvement in Ukondleka, DTI has established numerous smaller cooperatives throughout the Western Cape to which it provided some financial and technical support. However, due to their small size and a low economy of scale respondents noted that these cooperatives did not achieve the desired effect on value chain coordination. These cooperative are not the same as those envisaged by the SSF policy as the latter will be linked to a communal fishing use right, and thus will somehow have to be deregistered or incorporated in the policy post hoc given they have already been set up.

The delayed policy implementation may be partly attributable to limited capacity at the fisheries authority to implement the comprehensive SSF policy and the complex legal reform and institutional reorganisation required. Concerns are expressed by respondents over limited expertise of the fisheries authority to provide tailored support to different CBLEs and to intervene in chain coordination, in part due to a lacking availability of systematic information on value chain characteristics such as market values and selling prices. This lack of knowledge may render state-intervention in value chain relations and upgrading potentially ineffective as important opportunities and constraints to upgrading may not be taken into account. For instance, in 2013 steps were taken by the fisheries authority to establish a minimum price for lobster caught by small-scale fishers. It was pointed out by respondents working in processing and marketing that this minimum price was established without adequate consultation with existing companies who would have argued that the proposed price increase would have been unviable to implement overnight with adequate infrastructure realignment and marketing efforts. Others argue that the SSF policy does not sufficiently take into account the involvement of buyers and other downstream firms in SSF upgrading who coordinate value chains and directly influence the ability of individual fishers and collectives alike to upgrade their products, processes and functions. Given these concerns, respondents recognised that extensive consultation and cooperation with the private sector is important to realize sustained upgrading by CBLEs and to assure that external support to upgrading by SSF communities adequately takes into account existing value chain complexities and community level capacity building. 
The limitation in capacity to implement also reflects in the approach propagated by the fisheries authority to establish CBLEs. While the SSF policy gives communities the opportunity to influence the structure of CBLEs, the fisheries authority strongly favours the exclusive use of cooperatives as a right holding entity with additional marketing functions that are largely prescribed by the Department of Trade and Industry (DTI)'s Cooperatives Act (Act No. 14, 2005). The preference for these 'dual-function' cooperatives is due to the limited internal budget for implementation and the need to leverage financial capital and support from other Ministries. As a result, it is envisaged that the DTI will directly support these marketing cooperatives to engage in upgrading activities. At a public hearing the fisheries authority noted that this will include offering business development services, technological improvements, provision of machinery, cheap loans for equipment and tools, vehicles, infrastructure, and working capital.

Despite this support for these 'dual-function' cooperatives from the government in place of the original vision of a broader CBLE portfolio, fishers and civil society actors have voiced concern. The notion of merging rights and marketing functions under the label of a CBLE has been disputed by fishers holding IR permits as well as those holding commercial rights who support collective action in value chains but are reluctant to support communal ownership of fishing rights. According to Sowman et al. (2014) this may particularly be the case where fishers have had individual commercial quotas and must now access and sell marine resources through a collective system. According to both fishers and civil society groups, and as also illustrated in the Ukondleka case, there is a risk of elite capture in coastal communities. The result of these concerns is a split between fishers and associated civil society groups between those who prefer individual rights and those that prefer communal ownership of fishing rights. These are important issues to be taken into account, in part because buyers may be more likely to engage in supportive forms of value chain coordination with cooperatives that are not hampered by internal conflict. For example, one interviewed retailer stated its preference of communities to source lobster from is based largely on its internal stability, while other buyers voiced concerns over the risks of elite capture by leading individuals in cooperatives.

The government's choice to support cooperative-form CBLEs may be explained by the limited capacity of the national fisheries authority to support both right holding and producer marketing entities and to also tailor these to the specific needs of coastal communities. For example, during a public hearing attended during fieldwork the fisheries authority acknowledged that considerable state-capacity would be needed to support SSF communities, and that additional funding from other departments and the National Treasury would be needed to fully implement the SSF policy. Sowman et al. (2014) also note that the limited financial and staffing capacity of the state agencies, including those providing scientific support, hinder the adoption of the developmental role that the SSF policy requires. As a result, generic approaches tend to be implemented across diverse fishery contexts in South Africa. This aligns with the preference to exclusively use the DTI supported cooperatives. The proposed consultative process for CBLE establishment is likely to be time-consuming, while the implementation of the dual-function cooperatives may be faster due to the more executive implementation of DTI. And while DTI's policy on cooperatives does not necessarily align with the SSF policy on CBLEs, DTI does have a strong mandate, track-record and expertise in supporting the establishment of cooperatives. 
However, in order to successfully establish these cooperatives their focus should aim beyond generic administration of fishing rights and fulfilling a marketing function. As illustrated by the failure of the Ukondleka cooperative, the success of the dual-function cooperatives will be dependent on their ability to deal with a wider set of community relations rather than their rights allocation and marketing functions alone. Whether extra-transactional actors like the state can in fact facilitate collective action will to a large extent depend on their ability to cope with issues like internal conflict and elite capture (cf. Mitchell and Coles 2011). A failure to do so may render these dualfunction cooperatives ineffective while not addressing the wider goals of the SSF policies vision for CBLEs. Overall, while considerable attention has been given to the role of cooperatives in the vertical dimension of value chain governance, less attention has been given to the mode of governance that these cooperatives should take.

\section{Discussion}

The shift in the SSF policy towards promoting CBLEs demonstrates a new mode of state intervention in value chains in response to issues of weak user fisher rights and inequality in value chains (see Fig. 3). The goal of these CBLEs was to support upgrading in value chains, by improving the capability of fishers to not only increase the value of the lobster they produce, but also renegotiate their terms of incorporation in these value chains. In doing so CBLEs were intended to bring about a fundamental change to how marginalised fishing communities are organised and capture benefits from the fisheries they exploit. However, as outlined above, the involvement of DTI has placed more

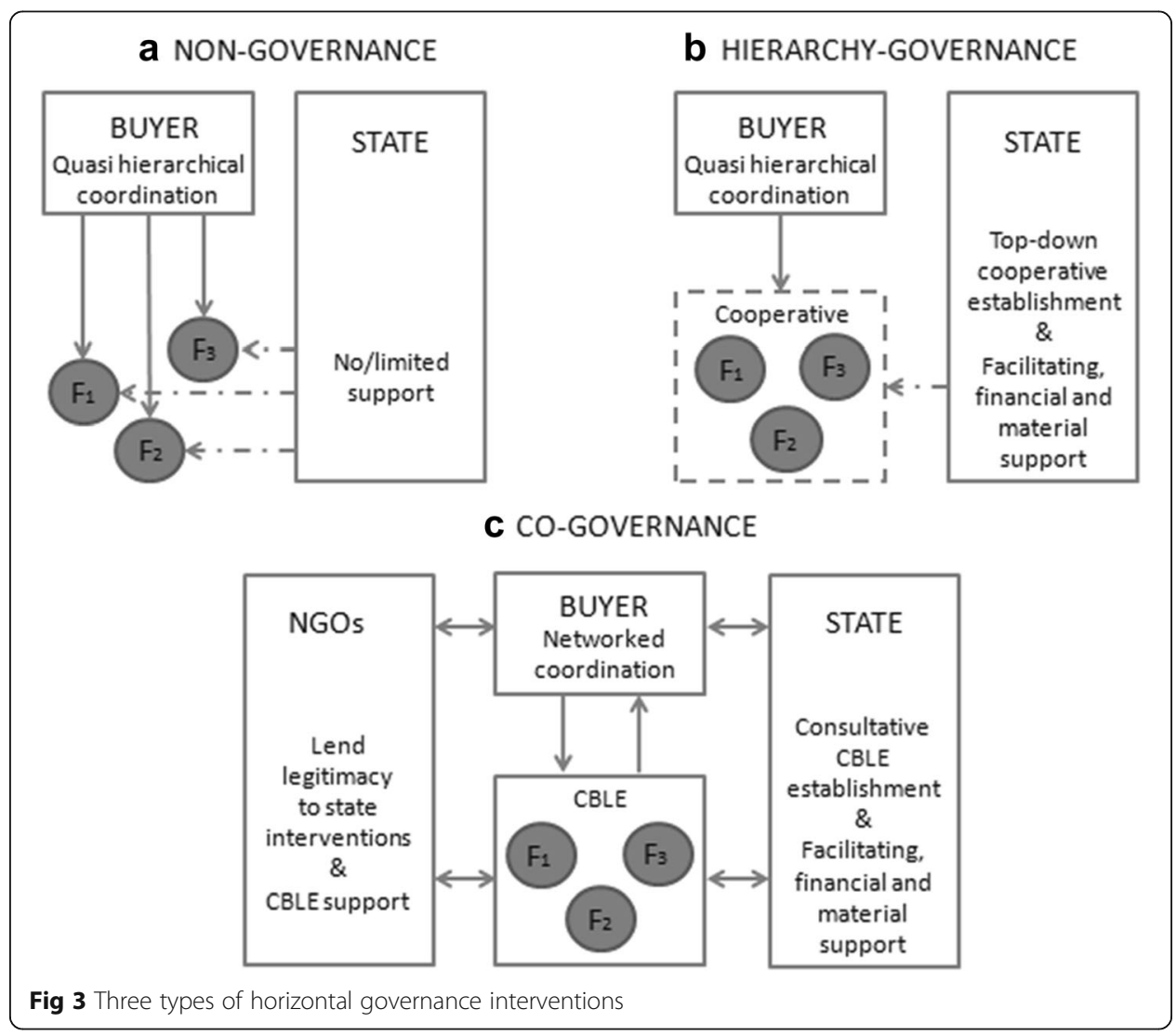


attention on the application of dual-function cooperatives that have a more functional and less transformative approach to upgrading. If the SSF policy is to successfully implement the original vision of a CBLE, not only will the DTI approach to cooperatives need to be adapted, but a wider governance approach may be required that includes networks of civil society actors.

In theoretical terms what we observe is the gradual confluence of both vertical and horizontal forms of coordination aimed at promoting upgrading in SSF communities. The initial intervention by the state was limited to some financial and material support by DTI to small cooperatives (which do not qualify as CBLEs) while the fisheries authority have avoided regulation as they geared up for a fisher identification and registration process under the SSF Policy Implementation. Meanwhile controversial loan systems used by buyers to indebt fishers are not regulated. The pre-SSF policy horizontal intervention represented a laissez-faire approach to extra-transactional influence over value chain coordination by what can be termed 'non-governance' (see A in Fig. 3). The initial DTI intervention had a negligible effect on value chain coordination, and did not benefit all fishers, most of whom remain positioned in value chains individually. This non-governance by the state reinforced power asymmetries by enabling buyers to maximise profits at the expense of fishers who remain vulnerable and unable to renegotiate their terms of incorporation in the chain (e.g. Markelova et al. 2009). As a result the value chain coordination of buyers remained captive in nature (see Gerreffi et al. 2005) and favoured commercial scale fishers already established in the industry. By identifying and classifying extra-transactional interventions by the state as a form of non-governance inequity is not only a function of value chain relations, but also determined by inaction by the state.

In contrast to the laissez-faire approach of non-governance, the development of the SSF policy brings in new modes of state intervention by proposing the establishment of CBLEs. While the stated preference for large dual function cooperatives has the potential to provide much needed support to the upgrading of SSF communities, they are not tailored to diverse community specific circumstances and interests. The exclusive use of dual function cooperatives can therefore be classified as 'hierarchical governance' (see B in Fig. 3) as the decision making power over the type of CBLE applied remains vested within the government. This case however shows that the dual-function cooperatives will have to deal with risks of internal conflict, elite capture and concerns over communal right allocations by some fishers. Uncertainty remains over the extent to which the generic dual-function cooperatives can adapt to these risks and pay adequate attention to the complex community functions of a CBLE. If not taken into account this could hamper implementation in the long term as demonstrated by the Ukondleka cooperative which is widely regarded as a pilot for the DTI cooperatives.

While the top-down decision on the applied type of CBLE is characterized as a hierarchical intervention, Ukondleka itself represents a form of self-governance. DTI as well as a civil society group provided support to the establishment of this cooperative, which could independently engage in price negotiations with buyers based on an economy of scale and enhanced capabilities, instead of being dependent on controversial brokering actors. Moreover the provision of technical support by DTI made the cooperative capable of engaging in product and process upgrading, to which support was also provided by the buyer. However, the cooperative did not sufficiently develop 
capabilities for self-governance that could maintain stable administration in the long term. Although the cooperative to an extent allowed for renegotiation of the vertical value chain relations, internal conflict, elite capture and lacking extra-transactional support in the long term prohibited its growth. Overall this intervention without adequate attention for long term support requirements does not appear to lead to durable collective action and upgrading of fishers in global value chains in the way originally envisaged by the SSF policy.

To implement CBLEs as a form of collective action that can lead to more equitable distribution of benefits, in terms of fishing rights and value chain upgrading, a shift to a co-governance mode of state intervention appears necessary (see $\mathrm{C}$ in Fig. 3). If the fisheries authority and DTI can successfully combine their efforts and collaborate with civil society groups to establish tailored CBLEs, state intervention may increase its legitimacy in the fishery while at the same time supporting fishers to renegotiate their relations with buyers in value chains. But for CBLEs to reach their full potential the fisheries authority will have to move past hierarchical interventions of DTI and instead tailor cooperative structures to the needs and interests of small-scale fishers (Coles et al. 2011), which differ per community and fish commodity (see Sowman et al. 2014). Furthermore, to address the constraints the fisheries authority has faced in delivering these functioning CBLEs the involvement of civil society groups appears relevant in terms of catalysing collective action and in enhancing the legitimacy of state-led intervention (Markelova et al. 2009). This was observed in the Ukondleka case where NGOs built legitimacy and support in the early stages of the cooperative, and only later facilitated financial and material support from DTI. The Ukondleka case also demonstrates the role private actors can play in furthering the SSF policy through renegotiation of prices once a requisite economy of scale was reached and through the provision of various upgrading services that are in the interest of fishers as well as buyers. Collaboration with these actors, and devolution of some tasks associated with the SSF policy implementation to civil society actors may address capacity constraints and may ensure that policy instruments adequately apply to the complex communities and value chains they govern.

Building on Kooiman (2003) and Jentoft and Chuenpagdee (2015), co-governance appears to offer a means of effectively designing cooperative arrangements that not only allow collective action by fishers, but also allows fishers to better engage with buyers through networked forms of coordination, and in doing so renegotiate their terms of incorporation in value chains. By fostering such collaborative approaches the public sector can enable community led upgrading strategies in small-scale fishery value chains. Co-governance also represents a more precise description than Gereffi and Lee's (2016) synergistic mode of value chain governance because it recognises the collaborative interplay between public and private actors. Here public and private actors as well as fisheries communities collaborate with a common purpose in mind. Such an approach can enhance the legitimacy of external initiatives towards collective action and upgrading through participation and/or consultation of stakeholders. It can also improve the applicability of policy instruments to the complex community and value chain structures, and may address governmental capacity constraints through joint action with private actors, NGOs and other line ministries. Furthermore, such a cogovernance approach may improve our understanding of the potential of market based 
instruments such as the Marine Stewardship Council and/or Fairtrade certification or others (see Bush 2010). Understanding the potential of this co-governance mode of cooperative formation is important given that buyers are more likely to commit to more collaborative market relations when collective action by fishers is stable. It is also important in countries like South Africa where state agencies, like the fisheries authority, have insufficient capacity to unilaterally implement ambitious upgrading policies.

Overall, the results show that government intervention in value chain relations can enable upgrading in both domestic and export value chains. However, these interventions should be perceived as a long-term process that creates a facilitative environment for previously disadvantaged fishers to be empowered to engage in a bottom-up process of community-led upgrading in current and new value chains that best serve socioeconomic development interests that may differ per community. In the context of this transition, learning and experimenting with different CBLE and value chain configurations will be important. Building on research findings in other sectors (Narrod et al. 2009; Markelova et al. 2009; Coles and Mitchell 2011), collective action will be a recurring precondition to these different upgrading avenues.

\section{Conclusion}

The empirical findings on upgrading of small-scale fishers in the South African West Coast rock lobster value chain have shown that extra-transactional intervention in support of upgrading and equity in transactions is possible. It also shows that the state has a key role to play in catalysing collective action to reach these goals. This insight opens up a range of opportunities for improving equity in transactions, exploring new avenues towards upgrading and reducing vulnerability to restrictive market relations with exploitative credit systems. But the effectiveness of extra-transactional intervention is subject to the range of existing complex market and community relations that can enable and constrain collective forms of upgrading. The SSF policy and comparable extra-transactional interventions will therefore have to adopt an approach that incorporates these complexities in order to effectively facilitate collective action and value chain upgrading.

We also conclude that co-governance should be a dominant approach in such interventions, while non- and hierarchy-governance interventions can in many cases work to the detriment of upgrading marginalized groups in value chains like small-scale fishers. Governmental inaction leaves this to be largely determined by those types of market relations that can be biased against small-scale fishers who are vulnerable to inequitable transactions and have limited capabilities to engage in upgrading, particularly when individually engaged in transactions. Meanwhile a hierarchical approach poses a risk that state-led upgrading initiatives are not effectively tailored to the differing needs and interests of the SSF group in question, and that they could inadequately align with the complexities of existing and potential value chains in which private actors also have a determining role to play.

These complexities make it particularly challenging for state actors to operate as a central governing unit that orchestrates upgrading and pro-poor value chains. While top-down regulation and oversight of controversial credit schemes is needed, effective extra-transactional intervention will therefore primarily have to adopt a co-governance approach taking into account the actors that are already operating in this field, by 
regulating those that are detrimental, and by making use of those that enable collective action, upgrading and equity in transactions.

These findings contribute to an ongoing discussion on the types of governance approaches that can be adopted by extra-transactional actors, and in doing so emphasises on the analysis of upgrading from a vertical to horizontal forms of coordination at various nodes of the chain. Interactive governance opens a fruitful means of identifying these new horizontal forms of coordination and places the analysis of upgrading in a broader institutional context. We therefore offer a means of better understanding state intervention in upgrading, and also identify the multiple roles in which states and civil society groups can support SSFs to improve their position. The next step is elaborating how this support affects new modes of market participation, meeting new sustainability demands of traceability and certification for example, and the way in which small holders can re-negotiate their inclusion in these value chains.

\section{Acknowledgements}

We thank the interviewees for sharing their experiences and insights and the two anonymous reviewers who contributed with constructive comments.

\section{Authors' contributions}

CW collected and analyzed the empirical material and provided the design of the research. All authors contributed to the interpretation of results and writing of the manuscript. All authors read, edited and approved the final manuscript.

\section{Competing interests}

The authors declare that they have no competing interests.

\section{Author details}

${ }^{1}$ Environmental Policy Group, Wageningen University, Wageningen, Netherlands. ${ }^{2}$ Department of Environmental and Geographical Sciences, University of Cape Town, Private Bag X3, Rondebosch 7701, Cape Town, South Africa.

Received: 4 May 2016 Accepted: 14 January 2017

Published online: 05 April 2017

\section{References}

Adhuri, D.S., L. Rachmawati, H. Sofyanto, and N. Hamilton-Hart. 2016. Green market for small people: Markets and opportunities for upgrading in small-scale fisheries in Indonesia. Marine Policy 63: 198-205.

Bailey, M., S.R. Bush, A. Miller, and M. Kochen. 2016a. The role of traceability in transforming seafood governance in the global South. Current Opinion in Environmental Sustainability 18: 25-32.

Bailey, M., S. Bush, P. Oosterveer, and L. Larastiti. 2016b. Fishers, fair trade, and finding middle ground. Fisheries Research 182: $59-68$

Bair, J., and Palpacuer, F. (2015). CSR beyond the corporation: contested governance in global value chains. Global Networks 15(s1), S1-S19.

Béné, C. (2006). Small-scale fisheries: assessing their contribution to rural livelihoods in developing countries. Rome: FAO Fisheries Circular No. 1008. Food and Agriculture Organization of the United Nations

Béné, C., G. Macfadyen, and E.H. Allison 2005. Increasing the contribution of small-scale fisheries to poverty alleviation and food security. Food and Agriculture Organization of the United Nations

Berkes, F., R. Mahon, P. McConney, R. Pollnac, and R. Pomeroy. 2001. Managing Small-scale Fisheries: Alternative Directions and Methods. Ottowa: International Development Research Centre.

Bjorndal, T., A. Child and A. Lem eds. 2014. Value chain dynamics and the small-scale sector: policy recommendations for small-scale fisheries and aquaculture trade. FAO Fisheries and Aquaculture Technical Paper No. 581. Rome, FAO. pp. 112

Blandon, J., S. Henson, and J. Cranfield J. 2009. Small-scale farmer participation in new agri-food supply chains: Case of the supermarket supply chain for fruit and vegetables in Honduras. Journal of International Development 21(7): 971-984.

Bush, S.R. 2004. Scales and sales: changing social and spatial fish trading networks in the Siiphandone fishery, Lao PDR. Singapore Journal of Tropical Geography 25(1): 32-50.

Bush, S.R. 2010. Governing 'spaces for interaction' for sustainable fisheries. Tijdschrift voor Economische en Sociale Geografie 101(3): 305-319.

Bush, S.R., and P. Oosterveer. 2007. The missing link: intersecting governance and trade in the space of place and the space of flows. Sociologia Ruralis 47(4): 384-399.

Bush, S.R., P. Oosterveer, M. Bailey, and A.P.J. Mol. 2015. Sustainability governance of chains and networks: a review and future outlook. Journal of Cleaner Production 107: 8-19.

Coles, C. and J. Mitchell 2011. Working together - Horizontal Coordination as an Upgrading Strategy. In Mitchell.J. and C. Coles Markets and rural poverty. Upgrading in value chains. p143-162. Earthscan, London

DAFF (Department of Agriculture, Forestry and Fisheries). 2012. Policy for the small-scale fisheries sector in South Africa. Pretoria: DAFF. 
Gereffi, G., and J. Lee. 2012. Why the world suddenly cares about global supply chains. Journal of supply chain management 48(3): 24-32.

Gereffi, G., and J. Lee. 2016. Economic and social upgrading in global value chains and industrial clusters: Why governance matters. Journal of Business Ethics 133(1): 25-38.

Gereffi, G., J. Humphrey, J. and T. Sturgeon 2005. The governance of global value chains. Review of international political economy 12(1): 78-104

Gibbon, P., J. Bair, and S. Ponte. 2009. Governing global value chains: an introduction. Economy and Society 37(3): 315-338.

Hamilton-Hart, N., \& Stringer, C. (2016). Upgrading and exploitation in the fishing industry: Contributions of value chain analysis. Marine Policy 63, 166-171.

Hellin, J., M. Lundy, and M. Meijer. 2009. Farmer organization, collective action and market access in Meso-America. Food Policy 34(1): 16-22.

Humphrey, J. and Schmitz, 2000, Governance and upgrading: Linking Industrial Cluster and Global Value Chain research. IDS Working Paper 120. Brighton: Institute of Development Studies.

Isaacs, M. 2011. Individual trasnferable quoats, poverty alleviation and challenges for small-country fisheries policy in South Africa. Maritime Studies 10(2): 63-84.

Jentoft, S., and R. Chuenpagdee. 2015. Enhancing the Governability of Small-Scale Fisheries Through Interactive Governance. In Interactive Governance for Small-Scale Fisheries, ed. S. Jentoft and R. Chuenpagdee, 727-747. Dordrecht: Springer.

Jentoft, S., and A. Davis. 1993. Self and Sacrifice: An Investigation of Small Boat Fisher Individualism and Its Implication for Producer Cooperatives. Human Organization. 52(4): 356-367.

Johnson, D.S. 2010. Institutional adaptation as a governability problem in fisheries: patron-client relations in the Junagadh fishery, India. Fish and Fisheries 11(3): 264-277.

Kooiman, J. 2003. Governing as Governance. London: SAGE.

Kooiman. J., M. Bavinck, S. Jentoft, R. Pullin. 2005. Fish for Life. Interactive Governance for Fisheries. MARE publication series No. 3. Amsterdam University Press, Amsterdam, 5: 94-95.

Kusumawati, R., Bush, S. R., \& Visser, L. E. (2013). Can patrons be bypassed? Frictions between local and global regulatory networks over shrimp aquaculture in East Kalimantan. Society \& Natural Resources 26(8): 898-911.

MacFadyen. G. and Corcoran.E. 2002. Literature review of studies on poverty in fishing communities and of lessons learned using the sustainable livelihoods approach in poverty alleviation strategies and projects. FAO, Fisheries Circular No.979

Markelova, H., R. Meinzen-Dick, J. Hellin, and S. Dohrn. 2009. Collective action for smallholder market access. Food policy 34(1): 1-7.

Mitchell, J., and C. Coles (eds.). 2011. Markets and rural poverty: Upgrading in value chains. London: Earthscan.

Narrod, C., D. Roy, J. Okello, B. Avendaño, K. Rich, and A. Thorat. 2009. Public-private partnerships and collective action in high value fruit and vegetable supply chains. Food Policy 34(1): 8-15.

Neilson, J. 2014. Value chains, neoliberalism and development practice: The Indonesian experience. Review of International Political Economy 21(1): 38-69.

Pérez-Ramírez, M., B. Phillips, D. Lluch-Belda, and S. Lluch-Cota. 2012. Perspectives for implementing fisheries certification in developing countries. Marine Policy 36(1): 297-302.

Ponte, S. 2008. Greener than thou: The political economy of fish ecolabeling and its local manifestations in South Africa. World Development 36(1): 159-175.

Ponte, S., and Ewert, J. (2009). Which way is "up" in upgrading? Trajectories of change in the value chain for South African wine. World Development, 37(10): 1637-50.

Ponte, S., and L. Van Sittert. 2007. The chimera of redistribution in post-apartheid South Africa:'Black Economic Empowerment'(BEE) in industrial fisheries. African Affairs 106: 437-462.

Poulsen, R.T., S. Ponte, and J. Lister. 2016. Buyer-driven greening? Cargo-owners and environmental upgrading in maritime shipping. Geoforum 68: 57-68.

Riisgaard, L., S. Bolwig, S. Ponte, A. Du Toit, N. Halberg, and F. Matose. 2010. Integrating poverty and environmental concerns into value-chain analysis: a strategic framework and practical guide. Development Policy Review 28(2): 195-216.

Ruddle, K. 2011. "Informal" Credit Systems in Fishing Communities: Issues and Examples from Vietnam. Human Organization. 70(3): 224-232.

Shiferaw, B., G. Obare, G. Muricho, and S. Silim. 2009. Leveraging institutions for collective action to improve markets for smallholder producers in less-favored areas. African Journal of Agricultural and Resource Economics 3(1): 1-18.

Sowman, M., J. Sunde, S. Raemaekers, and O. Schultz. 2014. Fishing for equality: Policy for poverty alleviation for South Africa's small-scale fisheries. Marine Policy 46: 31-42.

Webber, M.C., and P. Labaste. 2010. Building Competitiveness in Africa's Agriculture. A guide to value chain concepts and applications. Washington: World Bank. 